\title{
Clinical evaluation of reprocessed blades in LASIK
}

\author{
Avaliação clínica da utilização de lâminas reprocessadas no LASIK
}

\author{
Felipe Mallmann ${ }^{1}$ \\ Celina Murata ${ }^{2}$ \\ Ester Sakae Yamazaki ${ }^{3}$ \\ Mauro Campos ${ }^{4}$
}

\begin{tabular}{l} 
ABSTRACT \\
\hline Purpose: To evaluate outcome and complications in LASIK with re- \\
processed blades. Methods: Retrospective analysis of patients' charts \\
submitted to complete custom LASIK from January 2004 to June 2005 . \\
Inclusion criteria comprised surgical description of blade use and minimum \\
follow-up of 1 month. The blade was reprocessed following a clinic \\
protocol, from 1 to 3 times (reprocessed group) and results compared with \\
patients that underwent LASIK with first-use blades (first-use group). \\
Results: Two hundred fifty-one eyes of 135 patients were analyzed \\
(spherical equivalent of -3.69 (D). There was no statistical differences \\
between first-use group and reprocessed blade group regarding intraope- \\
rative(5.5\% vs 8.8\%), early (50.5\% vs 49.5\%) and late complications (33\% \\
vs $27.5 \%$ ), respectively. Uncorrected visual acuity $\geq 20 / 20$ (68.1\% vs \\
$66.9 \%$ ), aberrometry analysis (total RMS: 0.62 vs $0.64 \mu$ m) and safety \\
(85.7\% vs 83.1\%) were similar between groups (p>0.05). Conclusion: \\
Reprocessed blades following rigid sterilization protocol may have \\
similar outcomes and complications rates in LASIK surgery compared \\
to first-use blades.
\end{tabular}

Keywords: Keratomileusis, laser in situ/adverse effects; Postoperative complications; Refractive surgical procedures; Refractive errors; Equipment reuse
Trabalho realizado no Setor de Cirurgia Refrativa do Departamento de Oftalmologia da Universidade Federal de São Paulo - UNIFESP e Instituto da Visão.

${ }^{1}$ Estagiário do Setor de Cirurgia Refrativa da Universidade Federal de São Paulo - UNIFESP - São Paulo (SP) - Brasil.

${ }^{2}$ Estagiária do Setor de Cirurgia Refrativa da UNIFESP - São Paulo (SP) - Brasil.

${ }^{3}$ Pós-graduanda do Departamento de Oftalmologia da UNIFESP - São Paulo (SP) - Brasil.

${ }^{4}$ Livre Docente, Professor da UNIFESP - São Paulo (SP) - Brasil.

Endereço para correspondência: Felipe Mallmann. Rua Anita Garibaldi, 1.076/401 - Porto Alegre (RS) CEP 90450-001

Email: fkmallmann@hotmail.com

Recebido para publicação em 09.01.2007

Última versão recebida em 20.11.2007

Aprovação em 06.12.2007

Nota Editorial: Depois de concluída a análise do artigo sob sigilo editorial e com a anuência do Dr. José Américo Bonatti sobre a divulgação de seu nome como revisor, agradecemos sua participação neste processo.

\section{INTRODUCTION}

LASIK (laser in situ keratomileusis) has become one of the most frequently performed surgical operations in Ophthalmology both in Brazil and worldwide ${ }^{(1-3)}$. In spite of technical developments in recent decades ${ }^{(4)}$ and the advent of commercially available femtosecond lasers ${ }^{(5)}$, most surgeons still use mechanical microkeratomes to make the flaps ${ }^{(4,6)}$. In addition, many centers both in Brazil and abroad ${ }^{(4,6)}$ reuse the blades on the same patient or on more than one patient. However, there are no data in the literature that specifically compare the results and complications of LASIK with blades being used for the first time and LASIK with reused blades. The aim of this study is to describe and compare the outcomes and complications in LASIK using reprocessed blades and first-use blades.

\section{METHODS}

\section{Case selection and definition of the variables}

The medical records of patients who had undergone custom LASIK between January 2004 and June 2005 were reviewed. The sample was selected at random from a database used in a previous study and the inclusion criteria were as follows: intraoperative report filled out completely with a description of the number of times the blade had been used and a 
minimum of 1 month postoperative follow-up. Cases that did not include data on visual acuity, complications or refractions were excluded. The study group and control group were defined as the cases in which reprocessed blades and previously unused blades had been utilized, respectively. The following were considered intraoperative complications: corneal epithelial defect, dislodged flap, decentered flap, thin flap, irregular flap, buttonholed flap and free cap. A description of any of the following at a postoperative visit were considered early and late complications: flap folds, interface debris, superficial punctate keratopathy (SPK), diffuse lamellar keratitis (DLK) and epithelial ingrowth. The presence of microfolds was not considered a complication. We defined an improved or unchanged postoperative Snellen-chart best spectacle-corrected visual acuity (BSCVA) compared with preoperative BSCVA as indicative of safety. The treatment was considered effective when postoperative Snellen-chart uncorrected visual acuity (UCVA) was the same as or better than the preoperative BSCVA. Aberrometry was analyzed in terms of total higherorder aberrations (HOA), total spherical aberration and total (horizontal and vertical) coma.

\section{Preoperative assessment}

All patients underwent a complete ophthalmological examination prior to the operation. The following further tests were included: corneal topography (Corneal Analysis System v4.0 ${ }^{\circledR}$, EyeSys, EUA), ultrasonic pachymetry (Corneo-Cage Plus ${ }^{\circledR}$, Sonage, Inc, EUA), Orbscan ${ }^{\circledR}$ II v3.0E (Bausch \& Lomb Surgical, EUA) and aberrometry (LadarWave Custom Cornea ${ }^{\circledR}$, Alcon Laboratories, Inc, EUA).

\section{Surgical routine}

The patients were instructed to perform eyelid hygiene $2 \mathrm{x}$ daily and to use tobramycin eye drops $4 \mathrm{x}$ daily for three days before the procedure. All surgeries were customized and were carried out by surgeons in training using the LadarVision $4000^{\circledR}$ system (Alcon Laboratories Inc., USA) under supervision. All patients had a preoperative photo taken under miosis, and aberrometry was performed under cycloplegia ( 2 drops $10 \%$ phenylephrine $+1 \%$ tropicamide followed by 2 drops $1 \%$ cyclopentolate). After application of topical anesthetic (1\% proxymethacaine, 2 drops), antisepsis of the eyelids was performed with $5 \%$ povidone-iodine, the eyelashes were isolated with adhesive plastic and a disposable surgical drape and the lid speculum then put in position. The used microkeratomes were the Hansatome ${ }^{\circledR}$ (Bausch \& Lomb Surgical, USA) and Moria M2 ${ }^{\circledR}$ (Moria SA, France) with variable platforms and rings according to the required diameter of flap. The blades were always inspected for irregularities before the flap was made and discarded if necessary. They were used up to 4 times (reprocessed 3 times).

\section{Reprocessing the blades}

The blades in the Moria ${ }^{\circledR}$ Microkeratome (Moria ${ }^{\circledR}$, France) were sterilized up to 3 times using the following steps: 1) the blade was removed from the microkeratome head and cleaned with sterile distilled water; 2) the blade was inspected under a microscope; 3) it was put back in the microkeratome head; and 4) the whole assembly was sterilized in a Tuttnauer $2340 \mathrm{EK}^{\circledR}$ autoclave (Tuttnauer CO LTD, Israel) at $134^{\circ} \mathrm{C}$ for 3 minutes with sterile distilled water. The blades in the Hansatome ${ }^{\circledR}$ microkeratome (Accuglide ${ }^{\circledR}$, USA) were cleaned following the same procedure but were sterilized in ethylene oxide because they contained heat-sensitive components.

\section{Postoperative assessment}

The patients were assessed again 5-10 minutes after the procedure, when they were instructed to use a $0.3 \%$ ciprofloxacin / $0.1 \%$ dexamethasone eye drop for 15 days and artificial tear solution $4 x$ daily for 3 months. Further assessment was carried out one day after the operation and one week after the operation. The examination protocol was followed up at 1, 3, 6 and 12 months. In the early postoperative period (defined as up to 15 days after the surgery), UCVA and biomicroscopy were assessed. In the late postoperative period ( $1^{\text {st }}$ month or later) UCVA was measured, and refractometry under cycloplegia, aberrometry, biomicroscopy and tonometry were performed.

\section{Ethics and statistical analysis}

The study was approved by the UNIFESP Ethics in Research Committee, and the guidelines of the Helsinki Declaration were followed. Statistical analysis was carried out with SPSS 13.0 software, using an alpha error of 0.05. Non-parametric tests were used to analyze categoric variables, Student's $t$ test was used for quantitative variables with a normal distribution. The Mann-Whitney U was used to compare quantitative data when normality assumption was not valid.

\section{RESULTS}

A total of 251 eyes in 135 patients submitted to custom LASIK between January 2004 and June 2005 were analyzed. The mean preoperative spherical equivalent (SE) was $-3.69 \pm$ 1.23 diopters (D). Further demographic data are shown in table 1 .

A total of 160 procedures $(66.7 \%)$ were performed with reprocessed blades, of which 82 were being used for the $2^{\text {nd }}$ time ( $1^{\text {st }}$ reprocessing, $\left.51.2 \%\right), 61$ for the $3^{\text {rd }}$ time $\left(2^{\text {nd }}\right.$ reprocessing, $38.1 \%$ ) and 17 for the $4^{\text {th }}$ time $\left(3^{\text {rd }}\right.$ reprocessing, $10.7 \%$ ) (Figure 1). The most often used microkeratome was the Hansatome $(51.8 \%)$, and the mean number of times the blades were used was $2.01 \pm 0.94$. There were no intraoperative complications in $92.4 \%$ of the procedures, and no cases of a free cap or buttonholed flap were reported (Table 2). Epithelial defect was the most frequently described complication and occurred in 7 cases $(2.8 \%)$. There were no statistically significant differences between the groups, but when we divided the group of reprocessed blades into categories, an 


\begin{tabular}{|c|c|c|c|c|}
\hline Variables & Total (n) & Reprocesed (n) & Single-use (n) & $P^{*}$ \\
\hline Sex & & & & 0.71 \\
\hline Female & $55.4 \%(139)$ & $56.3 \% \quad(90)$ & $53.8 \%(49)$ & \\
\hline Male & $44.6 \%(112)$ & $43.8 \% \quad(70)$ & $46.2 \% \quad(42)$ & \\
\hline Race & & & & 0.76 \\
\hline White & $84.9 \%(213)$ & $85.0 \%(136)$ & $84.6 \% \quad(49)$ & \\
\hline Mixed & $4.8 \% \quad(12)$ & $5.1 \% \quad(7)$ & $5.5 \% \quad(5)$ & \\
\hline Black & $3.6 \% \quad(9)$ & $5.1 \% \quad(7)$ & $2.2 \% \quad(2)$ & \\
\hline Oriental & $6.8 \% \quad(17)$ & $6.3 \% \quad(10)$ & $7.7 \% \quad(7)$ & \\
\hline Age (years) & $30.9 \pm 8.0$ & $31.6 \pm 8.3$ & $29.8 \pm 7.3$ & 0.09 \\
\hline Right eye & $51.8 \%(130)$ & $46.3 \% \quad(74)$ & $61.5 \% \quad(56)$ & 0.20 \\
\hline Spherical equivalent (D) & $-3.69 \pm 1.23$ & $-3.66 \pm 1.15$ & $-3.74 \pm 1.36$ & 0.59 \\
\hline$B S C V A \geq 20 / 20$ & $90.4 \%(227)$ & $87.5 \%(140)$ & $95.6 \% \quad(87)$ & 0.03 \\
\hline \multicolumn{5}{|l|}{ Aberrometry (RMS. $\mu \mathrm{m})$} \\
\hline Total HOA & $0.40 \pm 0.14$ & $0.40 \pm 0.14$ & $0.38 \pm 0.12$ & 0.33 \\
\hline Spherical aberration & $0.19 \pm 0.13$ & $0.18 \pm 0.13$ & $0.19 \pm 0.13$ & 0.84 \\
\hline Coma & $0.22 \pm 0.12$ & $0.23 \pm 0.13$ & $0.21 \pm 0.11$ & 0.47 \\
\hline \multicolumn{5}{|l|}{ Microkeratome } \\
\hline Hansatome & $53.8 \%(135)$ & $58.1 \% \quad(93)$ & $46.2 \% \quad(42)$ & 0.07 \\
\hline Moria M2 & $46.2 \%(116)$ & $41.9 \% \quad(67)$ & $53.8 \% \quad(49)$ & \\
\hline Temperature $\left({ }^{\circ} \mathrm{C}\right)$ & $19.9 \pm 1.5$ & $20.0 \pm 1.5$ & $19.8 \pm 1.5$ & 0.45 \\
\hline Humidity (\%) & $50.9 \pm 5.0$ & $50.7 \pm 5.4$ & $51.4 \pm 4.3$ & 0.13 \\
\hline
\end{tabular}

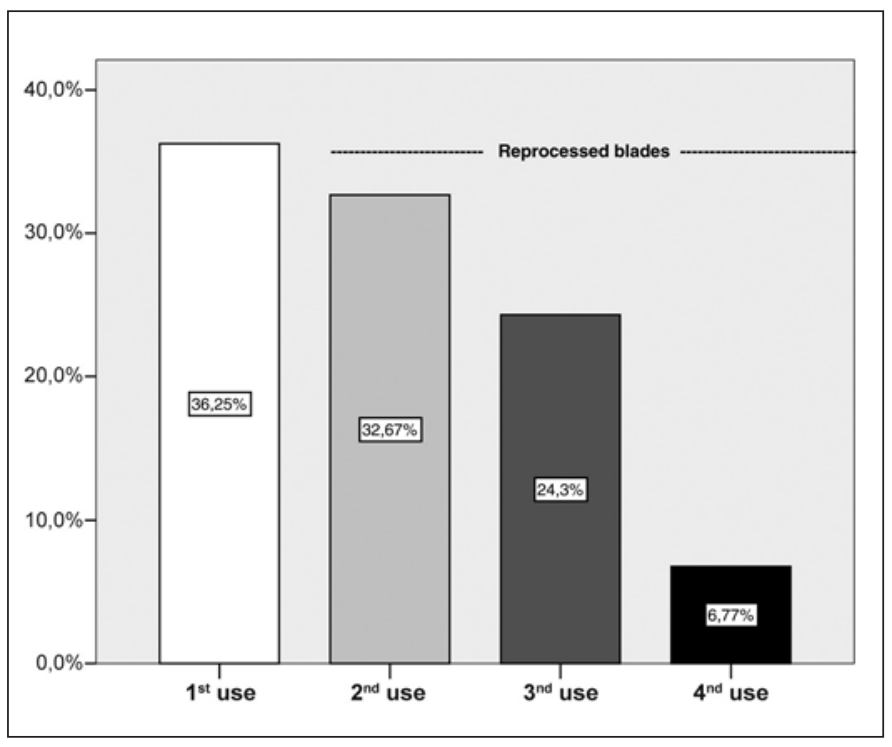

Figure 1 - Number of times of blade use. They were used up to 4 times (reprocessed 3 times).

increase in the frequency of intraoperative complications could be observed (Figure 2), particularly for blades used for the fourth time (although this was not statistically significant). This increase is the result of a greater prevalence of dislodged and decentered flaps in the group of reprocessed blades ( 8 cases compared with none for the first-use blades). Five complications were described in surgeries carried out with blades being used for the $2^{\text {nd }}$ time ( 2 displaced flaps, 2 de-epithelializa- tions and 1 off-center flap), six were described for operations with blades being used for the $3^{\text {rd }}$ time ( 2 off-center flaps, 2 deepithelializations, 1 dislodged flap and 1 irregular flap) and three for operations with blades being used for the $4^{\text {th }}$ time ( 1 displaced flap, 1 decentered flap and 1 epithelial defect).

During follow-up, complications were observed in $48.6 \%$ of the eyes at various stages of the early postoperative period (Table 2). The most common finding was the presence of interface debris (27.9\%). Similar percentages were observed in both groups with the exception of SPK, which had the highest incidence in the group of first-use blades $(25.3 \%$ vs. $16.9 \%$; not statistically significant). When patients were followed up after 1 month (late postoperative period), $13.9 \%$ of the eyes were found to have interface debris and $14.7 \%$ to have SPK in at least one of their postoperative visits. Folds were described in $4.8 \%$ of the flaps, of which four $(2.5 \%)$ were in the reprocessed group and $8(8.8 \%)$ in the first-use group (RR 0.28; $\mathrm{p}=0.03$ ). Diffuse lamellar keratitis (DLK) occurred in 7 eyes $(2.8 \%)$ in the early postoperative period, of which 5 cases (3.1\%) corresponded to reprocessed blades and $2(2.2 \%)$ to first-use blades. This complication during the early and late postoperative period occurred in 6 patients (9 eyes) and was the same for both groups, with a symmetrical distribution in terms of the number of times the blades had been used $(1 \mathrm{x}=3$ cases, $2 x=2,3 x=2,4 x=2$ ). In four of the 7 eyes there were no intraoperative complications, in 1 the flap was irregular, in 3 we identified interface bleeding (early-onset DLK) and epithelial defect was observed in 2 cases (late-onset DLK). Epithelial ingrowth was described in 12 eyes in the late postoperative 


\begin{tabular}{|c|c|c|c|c|c|c|}
\hline Complications & Total & (n) & Reprocessed (n) & First-use (n) & $\mathbf{R R}$ & $P$ * \\
\hline Intraoperative & $7.6 \%$ & (19) & $8.8 \%(14)$ & $5.5 \% \quad(5)$ & 1.65 & 0.35 \\
\hline Ephitelial defect & $2.8 \%$ & $(7)$ & $3.1 \% \quad(5)$ & $2.2 \% \quad(2)$ & 1.43 & 0.99 \\
\hline Disloged flap & $1.6 \%$ & (4) & $2.5 \% \quad(4)$ & $0 \%$ & - & 0.30 \\
\hline Descentered & $1.6 \%$ & (4) & $2.5 \% \quad(4)$ & $0 \%$ & - & 0.30 \\
\hline Thin flap & $0.4 \%$ & (1) & $0 \%$ & $1.1 \% \quad(1)$ & - & 0.36 \\
\hline Irregular flap & $1.2 \%$ & (3) & $0.6 \% \quad(1)$ & $2.2 \% \quad(2)$ & 0.28 & 0.30 \\
\hline Early complications & $48.2 \%(1$ & 121) & $46.9 \%(75)$ & $50.5 \%(46)$ & 0.93 & 0.57 \\
\hline Interface debris & $27.9 \%$ & (70) & $28.9 \%(46)$ & $26.4 \%(24)$ & 1.09 & 0.64 \\
\hline SPK & $19.9 \%$ & $(50)$ & $16.9 \%(27)$ & $25.3 \%(23)$ & 0.57 & 0.11 \\
\hline Folds & $5.2 \%$ & (13) & $4.4 \% \quad(7)$ & $6.6 \% \quad(6)$ & 0.64 & 0.45 \\
\hline DLK & $2.8 \%$ & $(7)$ & $3.1 \% \quad(5)$ & $2.2 \% \quad(2)$ & 1.42 & 0.64 \\
\hline Epithelial ingrowth & $0.4 \%$ & (1) & $0 \% \quad(0)$ & $1.1 \% \quad(1)$ & - & 0.36 \\
\hline Late complications & $29.5 \%$ & (74) & $27.5 \%(44)$ & $33.0 \%(30)$ & 0.83 & 0.36 \\
\hline Interface debris & $13.9 \%$ & (35) & $16.3 \%(26)$ & $9.9 \% \quad(9)$ & 1.04 & 0.16 \\
\hline SPK & $14.7 \%$ & (37) & $13.8 \%(22)$ & $16.5 \%(15)$ & 0.83 & 0.56 \\
\hline Folds & $4.8 \%$ & (12) & $2.5 \% \quad(4)$ & $8.8 \% \quad(8)$ & 0.28 & 0.03 \\
\hline DLK & $1.2 \%$ & (3) & $1.3 \% \quad(2)$ & $1.1 \% \quad(1)$ & 1.14 & 0.99 \\
\hline Epithelial ingrowth & $4.8 \%$ & (12) & $3.1 \% \quad(5)$ & $7.7 \% \quad(7)$ & 0.41 & 0.10 \\
\hline
\end{tabular}

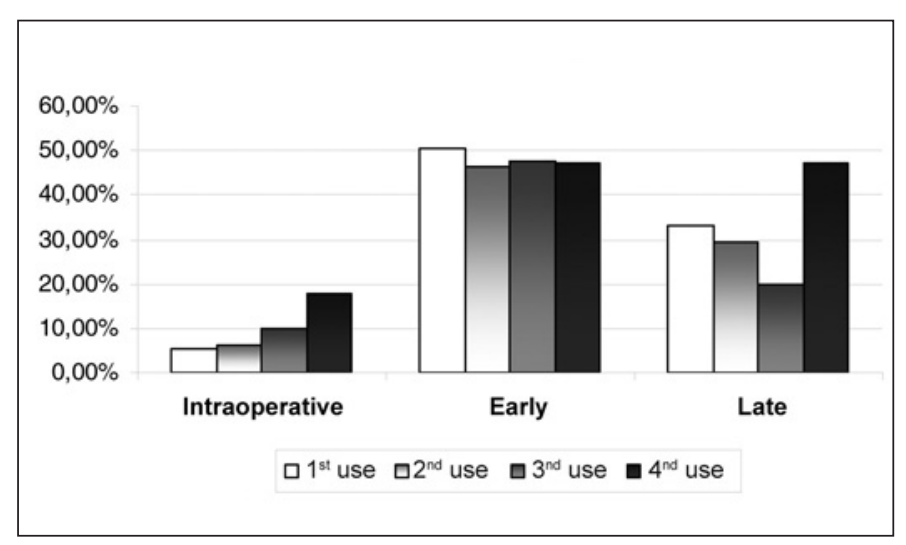

Figure 2 - Intraoperative and postoperative complications and number of times of blade use ( $p>0.05$, Chi-square test for all variables)

period $(4.8 \%)$, with the highest frequency (without a statistically significant difference) being in the first-use group $(7.7 \%$ vs. $3.1 \%$ ). Surgical intervention was not required for these complications, and there were no statistically significant differences between the groups corresponding to the first-use and reprocessed blades (Table 2).

Average follow-up was 6.6 months, and there was no statistically significant difference between the two groups in terms of postoperative spherical equivalent (SE), UCVA, safety, efficacy and aberrometry data (Table 3). The SE was 0.29 D, and $67.3 \%$ of the eyes had a UCVA $\geq 20 / 20$ at the last postoperative visit. The postoperative UCVA in $66 \%$ and $64 \%$ of the eyes in the reprocessed and first-use groups, respectively, was equal to or better than preoperative BSCVA (efficacy). Best spectacle-corrected postoperative VA in sixteen percent of the eyes (16.9\% vs. 14.3\%) decreased by one or more Snellen lines compared with the corresponding preoperative BSCVA. Postoperative aberrometry was also similar in both groups. Total higher-order aberrations were $0.63 \mu \mathrm{m}$ ( 0.64 vs. 0.62 for reprocessed and first-use group, respectively), spherical aberration was $0.34 \mu \mathrm{m}(0.33$ vs. 0.34$)$ and coma was $0.34 \mu \mathrm{m}(0.34$ vs. 0.32) (Table 3 and Figure 3 ). When we classified the reprocessed group in terms of the number of times the blades had been used and compared it with the first-use group, we also failed to find any statistically significant difference in terms of the complications and postoperative results. A firstuse blade was used in $31 \%$ of surgeries performed with the Hansatome microkeratome and in $42 \%$ of those performed with the Moria microkeratome. Comparison of the results for the two types of microkeratome did not reveal any statistically significant difference. However, the eyes submitted to LASIK with the Hansatome were found to have lower average HOA $(0.58$ vs. $0.69 \mu \mathrm{m})$, spherical aberration $(0.27$ vs. $0.40 \mu \mathrm{m})$, coma ( 0.31 vs. 0.36$)$ and postoperative $\operatorname{SE}(0.22$ vs. $0.36 \mathrm{D})$ than those operated on with the Moria $(p<0.05)$. It is noteworthy that the group operated on with the Moria microkeratome had a higher preoperative SE (-3.91 vs. $-3.50 \mathrm{D})$.

\section{DISCUSSION}

It has already been shown in the literature that using blades more than once results in a thinner flap ${ }^{(7-9)}$, and in studies using pigs' eyes, electron microscopy revealed a reduction in the quality of the cut ${ }^{(10)}$. However, in many Brazilian and international centers ${ }^{(2,6)}$, microkeratome blades are reused in bilateral surgery and in different patients, despite the absence of any studies comparing the results of this system and the possible risks. There is a lack of studies on this subject 


\begin{tabular}{|c|c|c|c|c|c|}
\hline \multicolumn{6}{|c|}{ Table 3. Final results } \\
\hline Variables & Total & Reprocessed & First-use & $\mathbf{R R}$ & $P^{*}$ \\
\hline Follow-up (months) & $6.6 \pm 4.1$ & $6.9 \pm 4.2$ & $6.1 \pm 4.1$ & - & 0.15 \\
\hline Spherical equivalent (D) & $0.29 \pm 0.49$ & $0.31 \pm 0.52$ & $0.25 \pm 0.45$ & - & 0.64 \\
\hline$B S C V A \geq 20 / 20$ & $67.3 \% \quad(169)$ & $66.9 \% \quad(107)$ & $68.1 \%(62)$ & 0.98 & 0.84 \\
\hline Efficacy & $66.1 \%(166)$ & $66.9 \% \quad(107)$ & $64.8 \%(59)$ & 0.94 & 0.74 \\
\hline Safety & $84.1 \% \quad(211)$ & $83.1 \% \quad(133)$ & $85.7 \%(78)$ & 1.18 & 0.59 \\
\hline \multicolumn{6}{|l|}{ Aberrometry (RMS. $\mu \mathrm{m}$ ) } \\
\hline Total HOA & $0.63 \pm 0.21$ & $0.64 \pm 0.21$ & $0.62 \pm 0.12$ & - & 0.28 \\
\hline Spherical aberration & $0.34 \pm 0.19$ & $0.33 \pm 0.21$ & $0.34 \pm 0.18$ & - & 0.90 \\
\hline Coma & $0.34 \pm 0.19$ & $0.34 \pm 0.19$ & $0.32 \pm 0.19$ & - & 0.29 \\
\hline
\end{tabular}

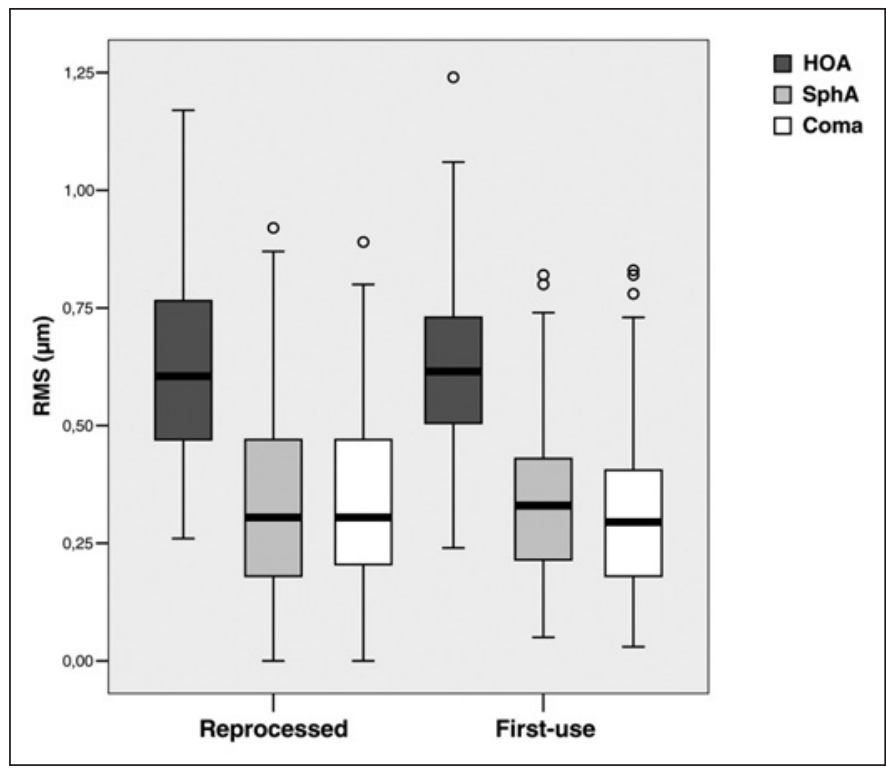

Figure 3 - Blox plot graph showing postoperative aberrometry $(p>0.05$, Mann-Whitney U-test) for reprocessed blade group and first-use blade group. Box represents $50 \%$ of sample and bold black line median. The ends of the vertical lines or "whiskers" indicate minimum and maximum data values, unless outliers are present in which case the whiskers extend to a maximum of 1.5 times the inter-quartile range. Circles outside the ends of the whiskers are outliers or suspect outliers. HOA: total high order aberration; SphA: total spherical aberration; Coma: total coma; RMS: Root mean square em micra.

and, except that by Prandi et al. who showed better functional results with thin flaps $(<100 \mu \mathrm{m})$ in cases of myopia, the impact of the loss of flap quality observed under electron microscopy on the complication rate and final results is, to our knowledge, not known ${ }^{(11)}$.

With the exception of the lower average age and higher percentage of patients with corrected VA $\geq 20 / 20$ in the firstuse group, we did not observe any differences in the preoperative demographic data of the two groups. This was also true in the intraoperative period, when we failed to observe any description of a buttonholed flap or free cap, and the flap complication rate remained similar to the average value reported in the literature (1.6\% vs. $0.3-1.26 \%)$. Contrary to what has been found in the literature, no cases of a thin flap were described in the reprocessed-blade group but were described in the first-use group, which also had a higher percentage of irregular flaps (0.6 vs. $2.2 \%, \mathrm{p}=0.36$ ). However, we have no data about pachymetry or flap diameter in the intraoperative period, and this could provide valuable information about the blade cut. It can be seen in figure 2 that there is a tendency for the complication rate to increase with the number of times the blade is reused. These findings are the result of our measurement criteria, which included a decentered or dislodged flap and epithelial defect as intraoperative complications. A decentered flap is primarily related to the position of the ring and the production of a vacuum, whereas epithelial defect is primarily related to the patient's corneal anatomy and physiology and irregularities in the microkeratome head. While a dislodged flap can indicate that the flap is thin, has a small pedicle and/or that a mistake was made during the surgery (e.g., insufficient time for the flap to adhere or lid speculum removed without due care). However, all the cases of dislodged flaps (4 eyes) occurred in surgeries performed with reprocessed blades, suggesting (although pachymetry data were not available) that the flaps in these cases were thin and had not been correctly classified.

The high rates for postoperative complications (35.5\%) are the result of measurement criteria, as we included a number of transitory anatomical changes that are not normally classified as complications in the literature (SPK and interface debris) and do not usually influence the final result. The incidences of feared complications such as DLK and epithelial ingrowth were similar to those described in the literature ${ }^{(1,4,12)}$ and did not increase in the reprocessed-blade group. Some authors suggest that reused blades can result in more (mainly metal) debris in the interface debris at the interface and that this would be a contributing factor to the higher incidence of DLK. This suggestion, however, was refuted in a recent cohort study by Stulting et al. ${ }^{(13)}$, who discarded the possibility that the microkeratome was the cause of the exaggerated inflammatory response at the interface and believed that thorough cleaning was the key to prevent this happening. In addition, there was no inflammatory reaction to this material in an expe- 
rimental model with rabbits ${ }^{(14)}$, and although there was a difference between the groups in terms of the debris present $(16.3 \%$ vs. $9.9 \%$ ), this was not statistically significant. The folds in the flap, on the other hand, which are more prevalent in higher corrections $^{(4,15)}$, appear to represent a lack of uniformity between the flap and the stroma rather than a change related to irregularities in the stromal bed (observable under an electron microscope) caused by the blade. Although both groups had the same preoperative spherical equivalent, the folds were more frequent in the group operated on with first-use blades. We were unable to explain this finding and believe that it may represent a variation by chance (alpha error). Superficial punctate keratopathy, however, was common during the postoperative period of LASIK and had the same incidence in both groups, suggesting that the use of reprocessed blades did not influence the incidence of dry eye.

With regard to the functional results, the reprocessed-blade group exhibited similar spherical equivalents, final visual acuity, degree of safety and efficacy compared with the firstuse blade group. Our results for safety were slightly lower $(84.1 \%$ vs. $96 \%)$ than those reported in the literature ${ }^{(4)}$ because we used a stricter criterion of loss of 1 or more (rather than 2 or more) lines, which in our opinion better reflects the expectations of the surgeon and patient. Nevertheless, the learning curve must also be taken into consideration. Another interesting result is the similarity between the postoperative aberrometry findings for both groups. It is well established in the literature $^{(3)}$ that the process of making the flap in itself generates aberrations, but contrary to expectations, no differences in total higher-order aberrations, spherical aberrations or coma were observed between the two groups, with the exception of the increase in coma average after the blade had been used four times (although this finding was not statistically different). We found higher values for aberrations and spherical equivalents in eyes operated on with the Moria microkeratome, probably as a result of the higher preoperative spherical equivalent in the group of surgeries performed with this apparatus. Another hypothesis is that these higher values are caused by the greater variations in, and smaller size of the flap produced with this microkeratome. However, we were unable to confirm this hypothesis as we did not have data on flap diameter or thickness. In a recent study ${ }^{(3)}$, no difference was found between the aberrations produced in operations with mechanical microkeratomes and those produced in operations with femtosecond lasers (IntraLase) apart from differences in the trefoil, which was larger in the former. We did not evaluate sensitivity to contrast, but extrapolating our results for aberrometry we can infer that there was probably no difference in final visual quality.

Finally, our study has limitations that are inherent to retrospective data collection and analysis. Our sample size meant that we did not have the power to show differences in low frequency intraoperative complications between the groups (beta error) ${ }^{(16)}$. Nevertheless, our data suggest that very careful reprocessing of blades from 2 microkeratomes up to 3 times can yield functional results and complication rates similar to those for first-use blades. Further studies with larger sample sizes are required to confirm or refute this hypothesis.

\section{RESUMO}

Objetivo: Analisar os resultados e complicações do uso de lâminas reprocessadas em cirurgias refrativas com a técnica de LASIK. Métodos: Estudo retrospectivo dos prontuários dos pacientes submetidos a LASIK personalizado durante janeiro de 2004 a junho de 2005. Foram incluídos pacientes que apresentavam relatório transoperatório completo (uso da lâmina) e seguimento mínimo de 1 mês após a cirurgia. O grupo controle foi constituído das lâminas com uso único enquanto no grupo das lâminas reprocessadas poderia variar de 2 a 4 vezes de uso. Resultados: Duzentos e cinqüenta e um olhos de 135 pacientes foram analisados e o equivalente esférico pré-operatório médio foi de -3,69(D). Não houve diferença significativa entre o número de complicações transoperatórias $(5,5 \%$ vs $8,8 \%)$, pós-operatórias imediatas $(50,5 \%$ vs $49,5 \%)$ e tardias (33\% vs $27,5 \%$ ) entre o grupo de lâminas com uso único e reprocessadas, respectivamente. Os resultados de AV sem correção pós-operatória $\geq 20 / 20(68,1 \%$ vs $66,9 \%)$, aberrometria (RMS total: 0,62 vs $0,64 \mu \mathrm{m})$ e segurança $(85,7 \%$ vs $83,1 \%$ ) foram similares entre os grupos $(p>0,05)$. Conclusão: $\mathrm{O}$ uso de até 4 vezes da lâmina metálica, seguindo reprocessamento adequado pode apresentar resultados e taxa de complicações semelhantes às cirurgias de LASIK realizadas com lâminas de uso único.

Descritores: Ceratomileuse assistida por excimer laser in situ /efeitos adversos; Complicações pós-operatórias; Procedimentos cirúrgicos refrativos; Erros de refração; Reutilização de equipamentos

\section{REFERENCES}

1. Pereira T, Forseto AS, Nosé W. Complicações per e pós-operatórias em 1000 olhos submetidos a LASIK. Arq Bras Oftalmol. 2001;64(6):499-506.

2. Victor G, Urbano A, Marçal S, Porto R, Francesconi CM, Forseto AS, et al. Primeiro censo brasileiro em cirurgia refrativa. Arq Bras Oftalmol. 2005; 68(6):727-33

3. Tran DB, Sarayba MA, Bor Z, Garufis C, Duh YJ, Soltes CR, et al. Randomized prospective clinical study comparing induced aberrations with IntraLase and Hansatome flap creation in fellow eyes: potential impact on wavefrontguided laser in situ keratomileusis. J Cataract Refract Surg. 2005;31(1): 97-105.

4. Melki SA, Azar DT. LASIK complications: etiology, management, and prevention. Surv Ophthalmol. 2001;46(2):95-116.

5. Kezirian GM, Stonecipher KG. Comparison of the IntraLase femtosecond laser and mechanical keratomes for laser in situ keratomileusis. J Cataract Refract Surg. 2004;30(4):804-11.

6. Sandoval HP, de Castro LE, Vroman DT, Solomon KD. Refractive surgery survey 2004. J Cataract Refract Surg. 2005;31(1):221-33.

7. Gailitis RP, Lagzdins M. Factors that affect corneal flap thickness with the Hansatome microkeratome. J Refract Surg. 2002;18(4):439-43.

8. Muallem MS, Yoo SY, Romano AC, Schiffman JC, Culbertson WW. Corneal flap thickness in laser in situ keratomileusis using the Moria M2 microkeratome. J Cataract Refract Surg. 2004;30(9):1902-8. 
9. Shemesh G, Leibovitch I, Lipshitz I. Comparison of corneal flap thickness between primary and fellow eyes using three microkeratomes. J Refract Surg. 2004;20(5):417-21.

10. Módis L Jr, Langenbucher A, Behrens A, Seitz B. Flap quality in single versus multiple use of the same blade in the flapmaker microkeratome. J Refract Surg. 2004;20(3):258-64.

11. Prandi B, Baviera J, Morcillo M. Influence of flap thickness on results of laser in situ keratomileusis for myopia. J Refract Surg. 2004;20(6):790-6.

12. Helena MC, Meisler D, Wilson SE. Epithelial growth within the lamellar interface after laser in situ keratomileusis (LASIK). Cornea. 1997;16(3):300-5. Comment in: Cornea. 1998;17(4):455-6.
13. Stulting RD, Randleman JB, Couser JM, Thompson KP. The epidemiology of diffuse lamellar keratitis. Cornea. 2004;23(7):680-8.

14. Bissen-Miyajima H, Minami K, Miyake-Kashima M, Taira Y, Nakamura M. Observation of the corneal flap interface with metal particles in a rabbit model. J Cataract Refract Surg. 2005;31(7):1409-13.

15. Charman NW. Mismatch between flap and stromal areas after laser in situ keratomileusis as source of flap striae. J Cataract Refract Surg. 2002;28(12): 2146-52.

16. Beck RW. Sample size for a clinical trial: why do some trials need only 100 patients and others 1000 patients or more? Ophthalmology. 2006;113(5):721-2. Comment in: Ophthalmology. 2007;114(3):615; author reply 615. 